Supplemental Information for:

\title{
OVERCOMING THE LAWS-IN-TRANSLATION PROBLEM: COMPARING TECHNIQUES TO TRANSLATE LEGAL TEXTS
}

\author{
Anthony J. DeMattee ${ }^{1}$ \\ Nick Gertler ${ }^{2}$ \\ Takumi Shibaike ${ }^{3}$ \\ Elizabeth A. Bloodgood ${ }^{4}$
}

\begin{abstract}
The benefits of computerized translations are their speed, accessibility, and cost. The risk is whether they are sufficiently precise for a given need. This note assesses the options available to translate legal text for socio-legal research. We evaluate three tools-DeepL, Google, Microsoft-and assess each one's ability to translate similar legal content enacted by the Brazilian, Chinese, French, Japanese, and Mexican governments. We demonstrate that machine translators are reliable and effective, particularly at higher levels of generality. They are fallible, however, and each is prone to making critical errors that may jeopardize research. We show that employing human translators to edit automated translations produces high-quality translations in one-third the time and at a fraction of the cost. This methodological contribution promises to enrich socio-legal research by establishing a translation protocol that is affordable, rigorous yet simple, and transparent. We propose that scholars use this method for comparative socio-legal research.
\end{abstract}

Keywords: machine translation, DeepL, Google, Microsoft, API, legal text, automated, reliability, presentation

Application Descriptions \& Procedures for Translation .................................................... 3

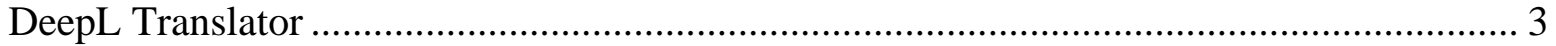

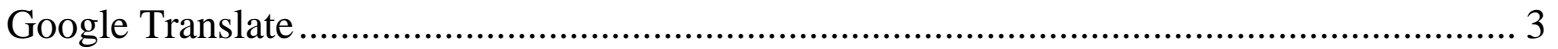

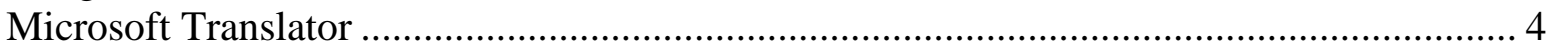

Amazon's Mechanical Turk................................................................................. 5

Source Text and Translated Text ..................................................................................... 7

Brazil: Legislation on Public Interest Civil Society Organizations .................................... 7

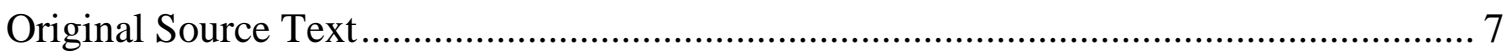

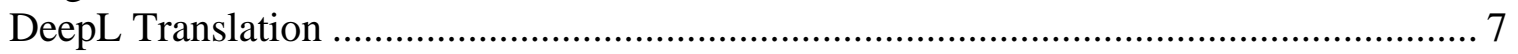

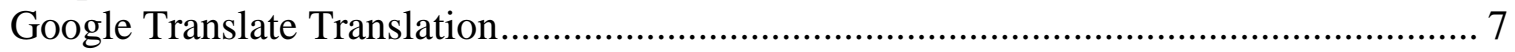

\footnotetext{
${ }^{1}$ Department of Political Science, Emory University anthony.demattee@emory.edu

${ }^{2}$ Concordia University, Montreal nickgertler@gmail.com

${ }^{3}$ School of Public Policy, University of Calgary takumi.s.com@gmail.com

${ }^{4}$ Department of Political Science, Concordia University, Montreal elizabeth.bloodgood@concordia.ca
} 
Google Chrome Translation........................................................................................ 7

Microsoft Word Translation ....................................................................................... 7

China: Charity Law of the People's Republic of China …….............................................. 8

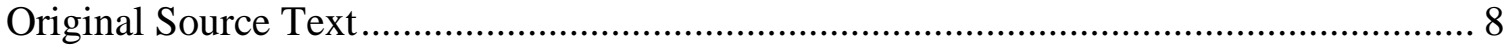

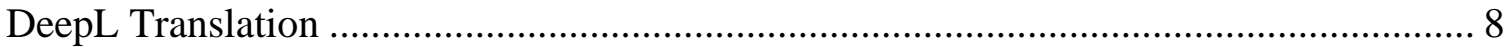

Google Translate Translation....................................................................................... 8

Google Chrome Translation........................................................................................ 8

Microsoft Word Translation ................................................................................... 8

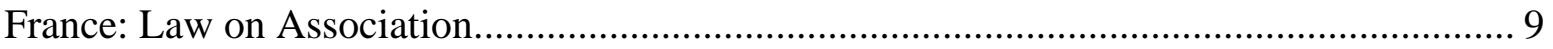

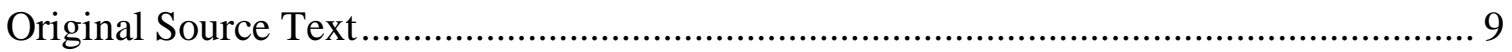

Google Translate Translation................................................................................. 9

Google Chrome Translation................................................................................... 9

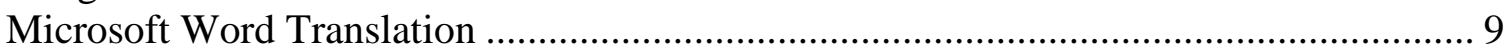

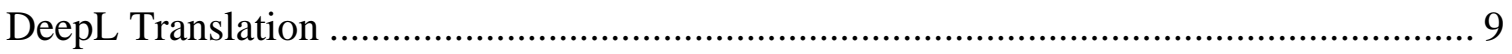

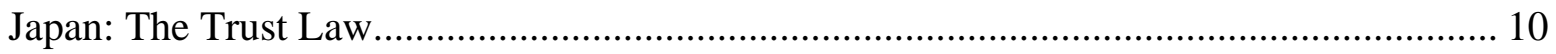

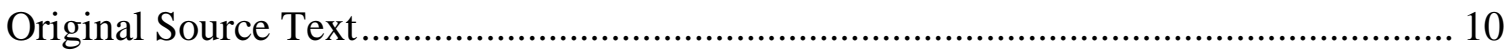

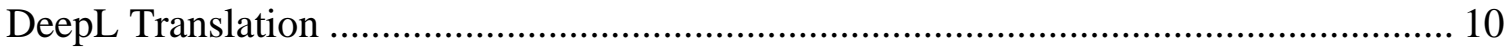

Google Translate Translation.................................................................................... 10

Google Chrome Translation..................................................................................... 10

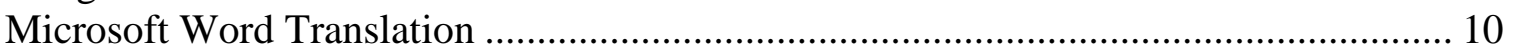

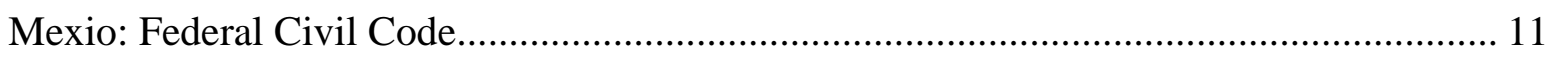

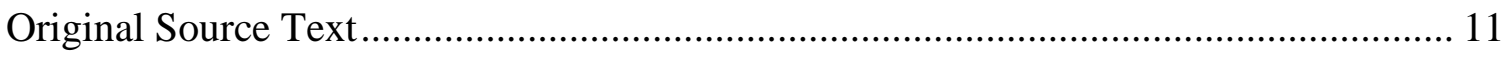

Google Translate Translation..................................................................................... 11

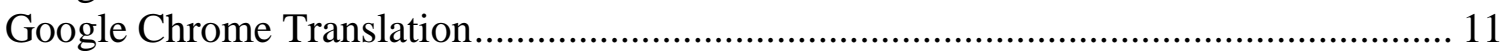

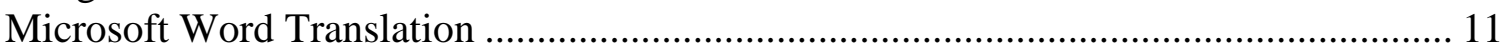

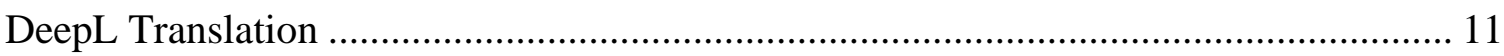

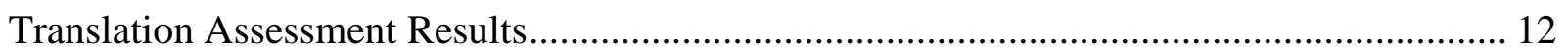

Five Measures Assessing Translation Applications ...................................................... 12

Table 1: Comparing Usability Across Translation Applications ..................................... 12

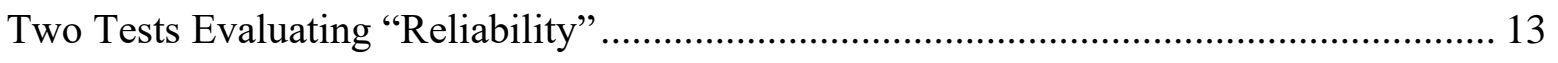

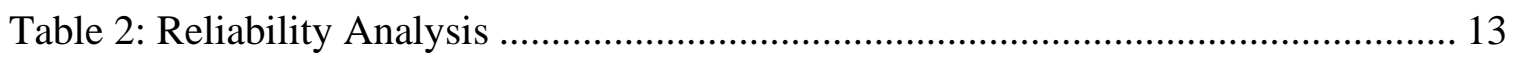

Table 3: Round Robin Reliability Analysis ................................................................... 14 


\section{APPLICATION DESCRIPTIONS \& PROCEDURES FOR TRANSLATION}

\section{DeepL Translator}

DeepL is an online, deep learning-based translation application that offers translation to and from eleven languages. It also supports translations into particular dialects, namely British and American English and Brazilian Portuguese. The free, online version of DeepL used in this project offers text-snippet translation up to 5,000 characters and document translation from .docx, .pptx, and .txt files up to about 35 pages. For full document translations on the free service, DeepL leaves a watermark at the top of the document. Otherwise, it maintains most formatting from the original document.

Of the applications analyzed here, DeepL offers by far the lowest generalizability (eleven languages). The free version of DeepL also comes with many limitations on flexibility, including the number of characters and files. However, these limitations are similar to those in Microsoft's and Google's applications. DeepL's main advantage is reliability, namely its purported ability to translate idiom and nuance. DeepL's paid plan offers certain services not tested in this study, including the ability to create custom dictionaries for domain-specific terminology.

The procedure tor translating documents in DeepL is as follows:

1. Open deepl.com/translator in any web browser.

2. Upload a document version of the law in question to DeepL. The interface accepts either .docx or .pptx file types. The free version limits users to three documents per month up to $5 \mathrm{MB}$ in size.

3. After selecting the target language, DeepL will translate the document and save a renamed version of it locally in the user's Downloads folder.

\section{Google Translate}

Google Translate can currently translate over 100 languages, making it one of the most generalizable MT applications available. Google Translate is primarily aimed at translating snippets of text (up to 5000 characters), although it does have some document translation capabilities. Translation is free to researchers with Internet access and is extremely flexible accepting a wide range of file types (.doc, .docx, .odf, .pdf, .ppt, .pptx, .ps, .rtf, .txt, .xls, and.xlsx). However, this application falls short on presentation, failing to maintain document formatting in most cases, so translations can be difficult to use and particular sections of text harder to find. Presentation can sometimes be improved by using the translation feature within the Google Chrome browser, which uses the expansive Google Translate API, allows for the translation of longer inputs (provided that they are in HTML format), and maintains document formatting. Unfortunately, translating in the Google Chrome browser limits flexibility in terms of intake file formats. This method also requires that the full text of the law be rendered on a single webpage, which may not be possible depending on data sources.

The procedure for translating documents using Google Translate is as follows:

1. Open translate.google.com in any web browser. On that page, navigate to the "documents" tab on the left-hand side of the page. 
2. Upload a document version of the law in question to Google Translate. Google Translate will accept documents in the following formats: .doc, .docx, .odf, .pdf, .ppt, .pptx, .ps, .rtf, .txt, .xls, and.xlsx. Individual documents must not exceed 10 MB in size.

3. Google Translate will now produce a webpage with a translated copy of the document. To save this translation, print the page (CTRL+P on Windows or Command+P on MacOS) and select "Print to PDF."

Google Chrome

The procedure for using Google Chrome to translate a law is as follows:

1. Open the law in the Google Chrome web browser. In some cases this may be as straightforward as loading a webpage. In other cases, it may be necessary to download the law as an HTML file and open the file directly in Chrome. For this method to work as intended, the entire text of the law must be rendered on a single page.

2. Once the file is open, right click and select translate webpage. Ensure that the detected language to translate and the destination language are correct, and then click translate.

3. Chrome will now begin translating the "visible" portions of the web page. To translate an entire law, gradually scroll down the page - ensuring that Chrome has translated each portion before moving on to the next.

4. Once the entire webpage has been translated print the page (CTRL+P on Windows or Command+P on MacOS) and select "Print to PDF." The resulting PDF file will be a complete and properly-formatted translation of the text in question.

\section{Microsoft Translator}

This method uses Microsoft's machine translation API, which is a part of Microsoft's Azur cloud platform. Microsoft's platform can translate over 70 languages. Microsoft Word integrates the API for use within the application. As a proprietary software, this method offers very low flexibility. For this method to work, the input file must be machine readable and in Microsoft Word format (the API only accepts .docx files, but .doc files can easily be saved as .docx before translation). Given that many countries only provide legal documents as PDF files, Microsoft Translator requires researchers to use a PDF reader to convert PDFs into Word documents. Microsoft Translator is particularly good at maintaining document formatting. While it accepts relatively few file formats, the near ubiquity of PDF and Microsoft Word files makes it useful in most cases. Microsoft's API occasionally fails, especially on longer documents, and the exact point at which it will fail is not documented. As a workaround, if attempting to translate a longer text, break the initial PDF into multiple pieces before proceeding.

The procedure for using Adobe Acrobat and Microsoft Word to translate a document is as follows:

1. Open the PDF document in Adobe Acrobat DC. Note that the PDF must be machine readable for this method to work reliably. If the document in question is already in .doc or .docx format, skip to step 3. 
2. In Adobe Acrobat, under the "File" menu select "Export to" and then "Microsoft Word" and "Word Document." Follow the dialogue and export the file.

3. Open the document in Microsoft Word. If the file has been converted from PDF, ensure that the formatting has largely been maintained before continuing.

4. In Microsoft Word, under the "Tools" menu select "Translate" and then "Translate document." In the right-hand side menu which will appear, select the correct input language and the desired output language, and then click translate.

5. Microsoft Word will open the translated document as a new file. Save that document as a new file.

\section{Amazon's Mechanical Turk}

We do not include Amazon's Mechanical Turk (MTurk) application in our assessment for reasons stated below, but we feel the platform deserved brief discussion. MTurk is a crowdsourcing platform that hires humans to perform explicit tasks, such as translations. The text to be translated is divided into multiple small jobs, which Amazon then distributes to MTurnk workers with an assigned monetary value for completion. The cost of a translation job depends on the length of text, the language, the number of available workers who speak a given language, the compensation they will accept, and other required qualifications. MTurk has the potential to provide verifiable human-performed translations at a relatively low cost. In practice, however, most of the completed translations seem to simply have been run through Google Translate by a MTurk worker. Because of the risk of slacking by translators, researchers are advised to submit each translation task multiple times, ${ }^{5}$ which increases the expense and effort required to obtain a quality translation. In terms of flexibility, the output document provided by MTurk is limited to CSV files. This format does not work well with special characters due to encoding issues, and particularly with languages that do not use the Roman alphabet, imposing practical limits on the generalizability of the service. Finally, MTurk is problematic in terms of presentation, as the division of the document into tasks inevitably destroys any formatting in the original document. As a result, simplicity is also low, as researchers are required to reassemble translated texts. Overall, MTurk translations are relatively expensive, often inaccurate, and provide little to no time-savings to the researcher.

The procedure for using Amazon Mechanical Turk to translate a document is as follows:

1. Divide the text to be translated into multiple small jobs. Mechanical Turk provides a template into which the jobs must be entered. It is recommended that the pieces of text be mixed so that no one can easily reverse engineer the nature or content of the project (for property rights protection and to prevent potential biases that might affect the translation).

2. Submit the jobs to Mechanical Turk. Each piece should be translated by more than one person (generally three) to enable verification between translators. At this stage it is possible to require qualifications (including education and employment background) from workers, however this may make it significantly less likely that the task is completed. Researchers with some software

\footnotetext{
5 "HIT Critique: Design Tips for Improving Results" published by Amazon Mechanical Turk (June 30 $0^{\text {th }}, 2013$ ). Retrieved from www.blog.mturk.com on May 31 ${ }^{\text {st }}, 2021$.
} 
development skills can create a test that workers need to take before they can complete the translations.

3. After the completion of the translation, the results are made available by worker (anonymized to an Amazon Worker ID) and the researcher needs to approve the work submitted. The final translations are available for download as CSV files.

4. Reassemble the translated text from the CSV into a formatted whole. 


\section{SOURCE TEXT AND TRANSLATED TEXT}

We use similar legal texts from five countries to test the comparative performance of the translations applications. We elected to use the legal definition of civil society organizations as specified in laws enacted by governments in Brazil, China, France, Japan, and Mexico.

\section{Brazil: Legislation on Public Interest Civil Society Organizations DA QUALIFICAÇÃO COMO ORGANIZAÇÃO DA SOCIEDADE CIVIL DE INTERESSE PÚBLICO (LEI No 9.790, DE 23 DE MARÇO DE 1999).}

Original Source Text ${ }^{6}$

Para os efeitos desta Lei, considera-se sem fins lucrativos a pessoa jurídica de direito privado que não distribui, entre os seus sócios ou associados, conselheiros, diretores, empregados ou doadores, eventuais excedentes operacionais, brutos ou líquidos, dividendos, bonificações, participações ou parcelas do seu patrimônio, auferidos mediante o exercício de suas atividades, e que os aplica integralmente na consecução do respectivo objeto social.

\section{DeepL Translation}

For the purposes of this Law, a private legal entity is considered nonprofit, which does not distribute, among its partners or associates, directors, officers, employees or donors, any operating surplus, gross or net, dividends, bonuses, participations or installments of its assets, earned through the exercise of its activities, and which fully applies them to the achievement of the respective corporate purpose.

\section{Google Translate Translation}

For the purposes of this Law, it is considered a nonprofit legal entity that does not distribute, among its partners or associates, directors, officers, employees or donors, any operational surpluses, gross or net, dividends, bonuses, participations or portions of its assets, earned through the exercise of its activities, and which fully applies them to the achievement of the respective corporate purpose.

\section{Google Chrome Translation}

For the purposes of this Law, it is considered a nonprofit legal entity that does not distribute, among its partners or associates, directors, officers, employees or donors, any operational surpluses, gross or net, dividends, bonuses, participations or portions of its assets, earned through the exercise of its activities, and which fully applies them to the achievement of the respective corporate purpose.

\section{Microsoft Word Translation}

For the purposes of this Law, a legal entity governed by private law shall be considered nonprofit-making persons that does not distribute, among its partners or associates, directors, directors, employees or donors, any operating surplus, gross or net, dividends, bonuses, equity or portions of its assets, earned through the exercise of its activities, and that fully applies them in the achievement of the respective corporate purpose.

\footnotetext{
${ }^{6}$ Article 1 of the Legislation on Public Interest Civil Society Organizations: Law 9.790 of March 23, 1999. Retrieved on January $10^{\text {th }}, 2021$ from www.planalto.gov.br/ccivil_03/Leis/L9790.htm.
} 


\title{
China: Charity Law of the People's Republic of China
}

中华人民共和国慈善法 (2016年3月16日第十二届全国人民代表大会第四次会议通过).

\author{
Original Source Text ${ }^{7}$ \\ 第八条 本法所称慈善组织, 是指依法成立、符合本法规定, 以面向社会开展慈善活动为 \\ 宗旨的非营利性组织。 \\ 慈善组织可以采取基金会、社会团体、社会服务机构等组织形式。
}

\section{DeepL Translation}

Article 8 The term "charitable organization" refers to a nonprofit organization established in accordance with the law, in compliance with the provisions of this Law, for the purpose of carrying out charitable activities in society.

Charitable organizations can take the form of foundations, social organizations, social service agencies and other organizations.

\section{Google Translate Translation}

Article 8 Charitable organizations as mentioned in this Law refer to nonprofit organizations established in accordance with the law, in compliance with the provisions of this Law, with the purpose of carrying out charitable activities for the society.

Charitable organizations can take organizational forms such as foundations, social groups, and social service organizations.

\section{Google Chrome Translation}

Article 8 The term "charitable organizations" as used in this law refers to nonprofit organizations established in accordance with the provisions of this law with the purpose of carrying out charitable activities for the society.

Charitable organizations can take the form of foundations, social groups, social service organizations and other organizational forms.

\section{Microsoft Word Translation}

Article 8 The term "charitable organization" as used in this Law refers to a nonprofit 营 organization 组织 established in accordance with the law, conforming to the provisions of this Law, and carrying out charitable activities for the benefit of the society.

Charitable organizations can take the 组织 form of foundations, social groups, social service organizations, etc.

\footnotetext{
${ }^{7}$ Chapter II Article 8 of the Charity Law of the People's Republic of China. Retrieved on January $10^{\text {th }}, 2021$ from http://www.gov.cn/zhengce/2016-03/19/content_5055467.htm.
} 


\section{France: Law on Association}

Loi du 1er juillet 1901 relative au contrat d'association (Version en vigueur depuis le 02 juillet 1901).

\section{Original Source Text ${ }^{8}$}

L'association est la convention par laquelle deux ou plusieurs personnes mettent en commun, d'une façon permanente, leurs connaissances ou leur activité dans un but autre que de partager des bénéfices. Elle est régie, quant à sa validité, par les principes généraux du droit applicables aux contrats et obligations.

\section{Google Translate Translation}

Association is the convention by which two or more people permanently pool their knowledge or their activity for a purpose other than sharing profits. It is governed, as to its validity, by the general principles of law applicable to contracts and obligations.

\section{Google Chrome Translation}

Association is the convention by which two or more people permanently pool their knowledge or their activity for a purpose other than sharing profits. It is governed, as to its validity, by the general principles of law applicable to contracts and obligations.

\section{Microsoft Word Translation}

Association is the convention by which two or more people permanently pool their knowledge or activity for a purpose other than to share benefits. It is governed, as to its validity, by the general principles of law applicable to contracts and obligations.

\section{DeepL Translation}

Association is the agreement by which two or more persons pool, on a permanent basis, their knowledge or activity for a purpose other than to share profits. It is governed, as to its validity, by the general principles of law applicable to contracts and obligations.

\footnotetext{
${ }^{8}$ Title I Article 1 of the Law on Association. Retrieved on January $10^{\text {th }}, 2021$ from https://www.legifrance.gouv.fr/jorf/id/JORFTEXT000000497458.
} 


\title{
Japan: The Trust Law
}

信託法 (平成十八年法律第百八号).

\author{
Original Source Text ${ }^{9}$ \\ 第二条 この法律において「信託」とは、次条各号に掲げる方法のいずれかにより、特 \\ 定の者が一定の目的（専らその者の利益を図る目的を除く。同条において同じ。）に従 \\ い財産の管理又は処分及びその他の当該目的の達成のために必要な行為をすべきものと \\ することをいう。
}

\section{DeepL Translation}

Article 2 The term "trust" as used in this Act means a trust that has been established by a specific person for a certain purpose (excluding the purpose of exclusively benefiting that person) by any of the methods listed in the items of the following Article. The same shall apply in the same Article). (2) The term "trust" as used in this Act means that a specified person shall manage or dispose of property and perform other acts necessary for achieving a certain purpose (excluding the purpose of exclusively benefiting that person) in accordance with the purpose (excluding the purpose of benefiting that person) by one of the methods listed in the following articles

\section{Google Translate Translation}

Article 2 The term "trust" in this law means that a specific person follows a certain purpose (excluding the purpose of exclusively pursuing that person's interests; the same applies in the same article) by any of the methods listed in the following items. It means performing necessary actions for the management or disposal of property and other achievement of the purpose.

\section{Google Chrome Translation}

Article 2 In this Act, the term "trust" means that a specific person follows a certain purpose (excluding the purpose of exclusively pursuing that person's interests; the same applies in the same article) by any of the methods listed in each item of the following Article. It means performing necessary actions for management or disposal of property and other achievement of the purpose.

\section{Microsoft Word Translation}

Article 2 (1) The term "trust" as used in this Act shall mean that a particular person shall have a certain purpose (excluding the purpose of pursuing the interests of such person) for a certain purpose (excluding the purpose of pursuing the interests of the person) by any of the methods listed in each item of the following Article. The same shall be in the same article. the management or disposition of property and other acts necessary for the achievement of such purposes in accordance with

\footnotetext{
${ }^{9}$ Chapter 1 Article 2 of the Trust Law (Act No. 108 of 2006). Retrieved on January 10 ${ }^{\text {th }}, 2021$ from https://elaws.egov.go.jp/document?lawid=418AC0000000108.
} 


\section{Mexio: Federal Civil Code \\ Código Civil Federal (2004)}

Original Source Text ${ }^{10}$

ARTÍCULO 2670.- Cuando varios individuos convinieren en reunirse, de manera que no sea enteramente transitoria, para realizar un fin común que no esté prohibido por la ley y que no tenga carácter preponderantemente económico, constituyen una asociación.

\section{Google Translate Translation}

ARTICLE 2670.- When several individuals agree to meet, so that it is not entirely transitory, to carry out a common purpose that is not prohibited by law and that is not predominantly economic, they constitute an association.

\section{Google Chrome Translation}

ARTICLE 2670.- When several individuals agree to meet, so that it is not entirely transitory, to carry out a common purpose that is not prohibited by law and that is not predominantly economic, they constitute an association.

\section{Microsoft Word Translation}

ARTICLE 2670.- Where several individuals agree to meet, so that it is not entirely transient, to carry out a common purpose that is not prohibited by law and which is not predominantly economic in nature, they constitute an association.

\section{DeepL Translation}

When several individuals agree to meet, in a manner that is not entirely transitory, to carry out a common purpose that is not prohibited by law and that is not of a predominantly economic nature, they constitute an association.

10 Title XI Article 2670 of the Federal Civil Code. Retrieved on January $10^{\text {th }}, 2021$ from https://mexico.justia.com/federales/leyes/codigo-civil-federal/libro-cuarto/parte-segunda/titulo-decimo-primero/. 


\section{TRANSLATION ASSESSMENT RESULTS}

\section{Five Measures Assessing Translation Applications}

We use five measures to evaluate and compare translation applications:

1) Generalizability - the number of languages available for text-to-text translation.

2) Flexibility - reflects the compatibilities of file formats in the applications. Limitations on flexibility come in three forms: intake format, file size, and output format.

3) Presentation - degree the application preserves the source text's formatting and layout.

4) Simplicity is the number of actions necessary to translate a single document, including preparing files to be readable in applications.

5) Reliability represents accuracy. The most important aspect of reliability is that translation maintains the meaning of original texts.

Table 1: Comparing Usability Across Translation Applications

\begin{tabular}{|c|c|c|c|c|}
\hline & DeepL Translator & $\begin{array}{l}\text { Google } \\
\text { Translate }\end{array}$ & $\begin{array}{l}\text { Google } \\
\text { Chrome }\end{array}$ & $\begin{array}{l}\text { Microsoft } \\
\text { Translator }\end{array}$ \\
\hline $\begin{array}{l}\text { Generalizability } \\
\text { Available Languages }{ }^{1}\end{array}$ & 11 & 108 & 108 & 72 \\
\hline $\begin{array}{l}\text { Flexibility } \\
\text { Intake }\end{array}$ & $. \operatorname{doc} x, . p p t x, . t x t$ & $\begin{array}{l}. \text { doc, .docx, .odf, } \\
\text {.pdf, .ppt, .pptx, } \\
. p s, . \text { rtf, .txt, .xls, } \\
\text {.xlsx }\end{array}$ & html & docx \\
\hline Size & $\begin{array}{l}\text { Not documented. } \\
\text { The free translator } \\
\text { limits document } \\
\text { size and quantity. }\end{array}$ & $\begin{array}{l}\text { 5,000 characters } \\
\text { for snippets; } 10 \\
\text { MB for } \\
\text { documents. }\end{array}$ & No limit & $\begin{array}{c}\text { Not documented- } \\
\text { fails on large } \\
\text { documents. }\end{array}$ \\
\hline Output & $\begin{array}{c}\text { Rendered in } \\
\text { format matching } \\
\text { intake. }\end{array}$ & $\begin{array}{c}\text { Rendered as } \\
\text { webpage. Can be } \\
\text { saved as HTML or } \\
\text { printed as PDF. }\end{array}$ & $\begin{array}{c}\text { Rendered as } \\
\text { webpage. Can be } \\
\text { saved as HTML or } \\
\text { printed as PDF. }\end{array}$ & $\begin{array}{l}\text { Word document } \\
\text { (DOCX). }\end{array}$ \\
\hline Presentation & & & & \\
\hline $\begin{array}{l}\text { Preserves Identifiers } \\
\text { Maintains Formatting }\end{array}$ & $\begin{array}{c}\text { Yes } \\
\text { Font styles; } \\
\text { formatting; tables; } \\
\text { page layout }\end{array}$ & $\begin{array}{c}\text { Yes } \\
\text { Font styles }\end{array}$ & $\begin{array}{l}\text { Yes } \\
\text { Font styles; } \\
\text { images; page } \\
\text { layout }\end{array}$ & $\begin{array}{c}\text { Yes } \\
\text { Font styles; } \\
\text { images; page } \\
\text { layout }\end{array}$ \\
\hline Protects Page Breaks & Yes & Yes & No & Yes \\
\hline $\begin{array}{l}\text { Simplicity } \\
\text { DOCX file } \\
\text { Machine-encoded PDF } \\
\text { PDF requiring OCR }\end{array}$ & $\begin{array}{l}0.4 \\
3.1 \\
\text { No }\end{array}$ & $\begin{array}{l}0.8 \\
1.6 \\
\text { No } \\
\end{array}$ & $\begin{array}{l}2.3 \\
3.5 \\
\text { No }\end{array}$ & $\begin{array}{c}3.4 \\
0 \\
\text { Yes }\end{array}$ \\
\hline
\end{tabular}

${ }^{1}$ Public reports from Google and Microsoft (accessed August 14 ${ }^{\text {th }}, 2020$ ), and DeepL (accessed January 10 ${ }^{\text {th }}, 2021$ ). 


\section{Two Tests Evaluating "Reliability"}

The first test uses native language speakers. For each language, two single-blinded evaluators independently assessed the source text and translated text at three levels. "Minor edits" are small, stylistic changes that improve flow or readability. "Critical edits" involve substantive changes that realign the translated text with the source text. Finally, each evaluator assesses whether the translated text maintains the source text's original meaning without any editing.

Table 2: Native Language Speaker Reliability Analysis

\begin{tabular}{|c|c|c|c|c|}
\hline & $\begin{array}{c}\text { DeepL } \\
\text { Translator }\end{array}$ & $\begin{array}{c}\text { Google } \\
\text { Translate }\end{array}$ & $\begin{array}{l}\text { Microsoft } \\
\text { Translator }\end{array}$ & $\begin{array}{c}\text { Human } \\
\text { Translators }\end{array}$ \\
\hline \multicolumn{5}{|l|}{ Brazilian Legal Text } \\
\hline Minor Edits & 2.5 edits & 2.5 & 1.5 & 4.2 \\
\hline Critical Edits & 2.5 edits & 0.8 & 0.8 & 0 \\
\hline Maintained Meaning & No & Yes & Yes & Yes \\
\hline Minutes to Edit Translation & 9.0 minutes & 4.1 & 4.5 & 5.1 \\
\hline Words Added/Removed & +1.6 words & +2.5 & -2.3 & +2.6 \\
\hline \multicolumn{5}{|l|}{ Chinese Legal Text } \\
\hline Minor Edits & 5.9 & 4.7 & 5.1 & 8.5 \\
\hline Critical Edits & 0 & 0 & 1.7 & 0 \\
\hline Maintained Meaning & Yes & Yes & No & Yes \\
\hline Minutes to Edit Translation & 7.8 & 7.5 & 11.9 & 8.5 \\
\hline Words Added/Removed & -2.9 & 0 & -11.9 & +12.3 \\
\hline \multicolumn{5}{|l|}{ French Legal Text } \\
\hline Minor Edits & 5.6 & 3.6 & 1.2 & 11.5 \\
\hline Critical Edits & 0 & 0 & 0 & 0 \\
\hline Maintained Meaning & Yes & Yes & Yes & Yes \\
\hline Minutes to Edit Translation & 3.3 & 3.6 & 4.8 & 8.7 \\
\hline Words Added/Removed & +1.1 & 0 & +1.2 & +13.4 \\
\hline \multicolumn{5}{|l|}{ Japanese Legal Text } \\
\hline Minor Edits & 0.4 & 0.8 & 2.3 & 3.4 \\
\hline Critical Edits & 3.1 & 1.6 & 3.5 & 0 \\
\hline Maintained Meaning & No & No & No & Yes \\
\hline Minutes to Edit Translation & 6.6 & 12.3 & 8.74 & 8.5 \\
\hline Words Added/Removed & -45.2 & +2.5 & -8.7 & 0 \\
\hline \multicolumn{5}{|l|}{ Mexican Legal Text } \\
\hline Minor Edits & 6.4 & 8.1 & 9.0 & 6.4 \\
\hline Critical Edits & 1.3 & 0 & 0 & 0 \\
\hline Maintained Meaning & Yes & Yes & Yes & Yes \\
\hline Minutes to Edit Translation & 19.2 & 41.9 & 21.8 & 18.9 \\
\hline Words Added/Removed & +1.3 & +5.4 & +2.6 & +1.3 \\
\hline \multicolumn{5}{|l|}{ Five-Law Average } \\
\hline Minor Edits & 4.2 & 3.9 & 3.8 & 6.8 \\
\hline Critical Edits & 1.4 & 0.5 & 1.2 & 0 \\
\hline Maintained Meaning & Yes $(6 / 10)$ & Yes $(8 / 10)$ & Yes $(6 / 10)$ & Yes $(10 / 10)$ \\
\hline Minutes to Edit Translation & 9.2 & 13.9 & 10.3 & 9.9 \\
\hline Words Added/Removed & -8.8 & +2.1 & -3.8 & +5.9 \\
\hline
\end{tabular}

All measures averaged across native language speakers (2 per country, 10 total). Measures of edits, minutes to edit, and words added/removed are all standardized to a common unit, per 100 words, for comparability and interpretability. Google Chrome is not included in this table due to extensive overlap with Google Translate. 
The second reliability test uses a series of round-robin translations. We translate the source text to other languages and then back-translate it to the original language. Each translation as an independent task; therefore, errors will compile as the text is translated multiple times. Reliability is the similarity between the source text and the final translation reverted to the original language. We use English and German-languages outside those studied - to conduct the reverse translations. We vary the number of translations from one to two languages to further test each application's stability. The similarity score to assess these backwards translations. They represent the percentages of words in the backwards translation that identically, nearly, or relatedly match the words in the source text.

Table 3: Round Robin Reliability Analysis

\begin{tabular}{|c|c|c|c|}
\hline & $\begin{array}{c}\text { DeepL } \\
\text { Translator }\end{array}$ & $\begin{array}{c}\text { Google } \\
\text { Translate }\end{array}$ & $\begin{array}{l}\text { Microsoft } \\
\text { Translator }\end{array}$ \\
\hline & $\begin{array}{c}\text { Total (Identical, Near, } \\
\text { Related) }\end{array}$ & $\begin{array}{c}\text { Total (Identical, Near, } \\
\text { Related) }\end{array}$ & $\begin{array}{c}\text { Total (Identical, Near, } \\
\text { Related) }\end{array}$ \\
\hline \multicolumn{4}{|l|}{ Brazilian Legal Text } \\
\hline English & $\mathbf{6 1 \%}(48 \%, 10 \%, 3 \%)$ & $\mathbf{5 4 \%}(51 \%, 2 \%, 2 \%)$ & $\mathbf{5 1 \%}(44 \%, 3 \%, 3 \%)$ \\
\hline German & $\mathbf{1 5 \%}(12 \%, 2 \%, 2 \%)$ & $7 \%(7 \%, 0 \%, 0 \%)$ & $\mathbf{2 8 \%}(21 \%, 3 \%, 3 \%)$ \\
\hline English to German & $\mathbf{2 8 \%}(18 \%, 3 \%, 7 \%)$ & $\mathbf{8 \%}(8 \%, 0 \%, 0 \%)$ & $\mathbf{2 8 \%}(21 \%, 3 \%, 3 \%)$ \\
\hline German to English & $47 \%(30 \%, 10 \%, 7 \%)$ & $8 \%(7 \%, 0 \%, 0 \%)$ & $\mathbf{2 8 \%}(21 \%, 3 \%, 3 \%)$ \\
\hline Similarity Average & $37 \%$ & $19 \%$ & $34 \%$ \\
\hline \multicolumn{4}{|l|}{ Chinese Legal Text } \\
\hline English & $\mathbf{8 5 \%}(68 \%, 0 \%, 17 \%)$ & $\mathbf{3 0} \%(30 \%, 0 \%, 0 \%)$ & $27 \%(27 \%, 0 \%, 0 \%)$ \\
\hline German & $96 \%(79 \%, 17 \%, 0 \%)$ & $\mathbf{0 \%}(0 \%, 0 \%, 0 \%)$ & $\mathbf{9 \%}(9 \%, 0 \%, 0 \%)$ \\
\hline English to German & $\mathbf{6 0 \%}(52 \%, 0 \%, 8 \%)$ & $\mathbf{0 \%}(0 \%, 0 \%, 0 \%)$ & $\mathbf{9 \%}(9 \%, 0 \%, 0 \%)$ \\
\hline German to English & $\mathbf{7 8 \%}(78 \%, 0 \%, 0 \%)$ & $\mathbf{0 \%}(0 \%, 0 \%, 0 \%)$ & $\mathbf{9 \%}(9 \%, 0 \%, 0 \%)$ \\
\hline Similarity Average & $80 \%$ & $7 \%$ & $14 \%$ \\
\hline \multicolumn{4}{|l|}{ French Legal Text } \\
\hline English & $\mathbf{9 2 \%}(81 \%, 8 \%, 2 \%)$ & $75 \%(63 \%, 6 \%, 6 \%)$ & $\mathbf{8 3 \%}(73 \%, 10 \%, 0 \%)$ \\
\hline German & $71 \%(54 \%, 13 \%, 4 \%)$ & $\mathbf{1 0 \%}(10 \%, 0 \%, 0 \%)$ & $\mathbf{4 2 \%}(38 \%, 2 \%, 2 \%)$ \\
\hline English to German & $\mathbf{6 1 \%}(40 \%, 15 \%, 6 \%)$ & $\mathbf{1 0 \%}(10 \%, 0 \%, 0 \%)$ & $40 \%(31 \%, 4 \%, 4 \%)$ \\
\hline German to English & $69 \%(52 \%, 13 \%, 4 \%)$ & $\mathbf{1 0 \%}(10 \%, 0 \%, 0 \%)$ & $33 \%(23 \%, 6 \%, 4 \%)$ \\
\hline Similarity Average & $73 \%$ & $27 \%$ & $50 \%$ \\
\hline \multicolumn{4}{|l|}{ Japanese Legal Text } \\
\hline English & $\mathbf{5 0 \%}(50 \%, 0 \%, 1 \%)$ & $26 \%(24 \%, 0 \%, 2 \%)$ & $\mathbf{8 \%}(8 \%, 0 \%, 0 \%)$ \\
\hline German & $\mathbf{3 1 \%}(29 \%, 0 \%, 2 \%)$ & $\mathbf{1 0 \%}(8 \%, 0 \%, 2 \%)$ & $\mathbf{5 5 \%}(54 \%, 0 \%, 1 \%)$ \\
\hline English to German & $\mathbf{3 8 \%}(36 \%, 0 \%, 2 \%)$ & $\mathbf{9 \%}(8 \%, 0 \%, 1 \%)$ & $\mathbf{0 \%}(0 \%, 0 \%, 0 \%)$ \\
\hline German to English & $\mathbf{3 1 \%}(30 \%, 0 \%, 2 \%)$ & $5 \%(5 \%, 0 \%, 0 \%)$ & $\mathbf{0 \%}(0 \%, 0 \%, 0 \%)$ \\
\hline Similarity Average & $38 \%$ & $12 \%$ & $16 \%$ \\
\hline \multicolumn{4}{|l|}{ Mexican Legal Text } \\
\hline English & $40 \%(34 \%, 0 \%, 5 \%)$ & $\mathbf{6 8 \%}(62 \%, 0 \%, 5 \%)$ & $41 \%(35 \%, 3 \%, 3 \%)$ \\
\hline German & $\mathbf{5 4 \%}(43 \%, 5 \%, 5 \%)$ & $\mathbf{2 4 \%}(24 \%, 0 \%, 0 \%)$ & $\mathbf{3 5 \%}(30 \%, 3 \%, 3 \%)$ \\
\hline English to German & $\mathbf{5 4 \%}(43 \%, 5 \%, 5 \%)$ & $24 \%(24 \%, 0 \%, 0 \%)$ & $\mathbf{3 5 \%}(30 \%, 3 \%, 3 \%)$ \\
\hline German to English & $\mathbf{5 4 \%}(43 \%, 5 \%, 5 \%)$ & $\mathbf{2 4 \%}(24 \%, 0 \%, 0 \%)$ & $\mathbf{3 5 \%}(30 \%, 3 \%, 3 \%)$ \\
\hline Similarity Average & $50 \%$ & $35 \%$ & $36 \%$ \\
\hline
\end{tabular}

Similarity scores represented in percentages at four different thresholds: (i) total; (ii) identical one-for-one exact wording between texts; (iii) near expands the similar score to include the same word in a slightly different form - e.g., 'slow' and 'slowly'; (iv) related expands the score to include synonyms - e.g., 'fast' and 'quick'. Similarity scores calculated using online plagiarism checker www.copyleaks.com rounded to the nearest whole number. 